\title{
Are You Afraid to Write a Manuscript? If So, a Brief Communication Might Be Right for You
}

\author{
Mary Beth Farrell, MS, CNMT, NCT, FSNMMI-TS
}

Intersocietal Accreditation Commission

$\mathbf{I}$ used to be afraid of writing a manuscript. I was scared because I had never written one before. What if I looked stupid? I had no idea what sections were required. How long was it supposed to be? I did not know how to format the manuscript, much less the references. What if I mistreated a semicolon? And let us not forget the dreaded writer's block.

If you have a research project that you would like to see published but are a scaredy-cat like me, consider writing a brief communication. Brief communications are a perfect place for first-time investigators to get published, as the process is less daunting.

\section{WHAT ARE BRIEF COMMUNICATIONS?}

Brief communications are short (hence the word "brief") research articles that can take several different formats. They can be mini original research articles that follow the traditional Introduction, Methods, Results, and Conclusion format. A brief communication can also relay valuable information on some teaching point, novel idea, unique approach, or innovative technology. It could be the results of a pilot study, survey, or quality improvement activity.

The best idea for a brief communication is an abstract and poster presented at a scientific meeting such as the SNMMI annual meeting. Each year, the scientific ideas from over 100 technologists and 40 students are lost because the results never go any further than the poster or abstract published in the JNMT. They never grow up to be full-fledged manuscripts that include detailed methods and results sections. Did you know that most medical journals will not let authors cite an abstract over 2 years old? Lost, lost, lost. When you consider that annual meeting abstracts are usually around 500 words, a significant writing chunk is already completed.

Received Oct. 31, 2017; revision accepted Dec. 14, 2017.

For correspondence or reprints: Mary Beth Farrell, Intersocietal Accreditation Commission, 27 Boxwood Lane, Langhorne, PA 19047.

E-mail: farrell@intersocietal.org

Published online Feb. 2, 2018.

COPYRIGHT @ 2018 by the Society of Nuclear Medicine and Molecular Imaging. DOI: $10.2967 /$ jnmt.117.204479

\section{WHAT ARE THE RULES FOR BRIEF COMMUNICATIONS?}

The JNMT information for authors can be found at http:// tech.snmjournals.org/site/misc/JNMT Info for Authors.pdf, and the website for submitting your article to the JNMT can be found at https://submit-jnm.snmjournals.org/.

In JNMT, brief communications can be a maximum of 2,500 words. "Twenty-five hundred words!" you say? Calm down, those 2,500 words include the title page, abstract, text, disclosure, acknowledgments, references, tables, and figure legends.

To help, here are some rough estimates from manuscripts I have published (Table 1). A double-spaced page with 1inch margins is about 300 words. If you use longer words than I do, you might have fewer words per page. There are no rules that say you must use all 2,500 words; you just cannot go over 2,500.

You will also need to submit a cover letter with your manuscript providing a compelling reason why your brief communication should be published. A copyright transfer agreement must be signed by all authors and submitted (https://tech.snmjournals.org/site/misc/ifora.xhtml). Other supplementary material such as appendices or questionnaires can be provided for online publication.

\section{WHAT HAPPENS AFTER I SUBMIT?}

After you submit your manuscript, 2 independent reviewers are assigned to evaluate your work. The peer reviewers grade your paper on originality, methodology, presentation, and impact on patient care or future research. Priority to publish is based on the manuscript score.

TABLE 1

Average Number of Words per Section for a Brief Communication

\begin{tabular}{|c|c|}
\hline Section & Estimated number of words \\
\hline Title page & 150 \\
\hline Abstract & 150 \\
\hline Text & 1,400 ( 41/2 pages) \\
\hline Tables and figure legends & 500 \\
\hline $\begin{array}{l}\text { References (assuming } 10 \\
\text { references at } 30 \text { words each) }\end{array}$ & $250-300$ \\
\hline Total & 2,500 \\
\hline
\end{tabular}


Each reviewer will also make comments on your manuscript. But do not worry, it is not like the scene in the movie "A Christmas Story" where the teacher calls the students dolts and gives them Fs. The reviewers will make helpful, friendly suggestions on how to improve the article. I have frequently found that the comments from a reviewer help to strengthen my manuscripts. The peer review process generally takes a couple of weeks.

After the peer reviewers have completed their assessment, the Editor will make the final decision and contact you. If you are lucky, your manuscript will be accepted without the need for revision. However, that is rare. Most documents need either minor or major revisions. I have never had a manuscript accepted without having to make changes. In the worst-case scenario your manuscript is declined, but you can always rewrite the material using the reviewer's comments as guidance and then resubmit the article. I have had to do this several times too. Do not give up!

\section{CONCLUSION}

I am confident that if I can compose a manuscript and get it published, anyone can. Consider submitting a brief communication as a trial balloon. Speaking of balloons, you will need some to celebrate after your paper is published. So, get busy. And in case you were counting, this editorial is 862 words (about one third of a brief communication). 